\title{
Inhibitory effect of anti-mouse egg serum on fertilization in vitro and in vivo in the mouse
}

\author{
Y. Tsunoda \\ National Institute of Animal Industry, Chiba-shi, 280 Japan
}

It has been reported that heteroimmune anti-ovary serum can block sperm penetration of the zona pellucida in vitro in hamsters (Shivers, Dudkiewicz, Franklin \& Fussell, 1972; Oikawa \& Yanagimachi, 1975; Tsunoda \& Chang, 1976a), mice (Jilek \& Pavlok, 1975) and rats (Tsunoda \& Chang, 1976b). Passive immunization with anti-ovary serum can also prevent fertilization in vivo in hamsters (Oikawa \& Yanagimachi, 1975; Tsunoda \& Chang, 1976d), mice (Jilek \& Pavlok, 1975; Tsunoda \& Chang, 1976d) and rats (Tsunoda \& Chang, 1976d). Inhibition of pregnancy by isoimmunization with ovarian extracts has been observed in guinea-pigs (Porter, 1965) and mice (Tsunoda \& Chang, 1976c). It therefore seems possible that inhibition of fertilization by anti-ovary serum is caused by a zona pellucida-specific antigen(s) which is derived from the ovary. I therefore examined the effect of an antiserum against mouse eggs on fertilization in mice.

The antigen for immunization was obtained from cumulus-free (denuded) eggs from mature ddY mice (closed colony) induced to superovulate with PMSG and HCG. They were killed 14 to $18 \mathrm{~h}$ after injection of HCG. The eggs in the cumulus clot were recovered from the ampulla and treated with $0.05 \%$ hyaluronidase in Ringer solution containing $4 \mathrm{mg}$ bovine serum albumin (BSA)/ml. After the dispersion of follicular cells, the eggs were washed three times in the Ringer solution without hyaluronidase and BSA. The denuded eggs in Ringer solution were frozen and thawed 10 times and homogenized in a glass homogenizer. This homogenate of eggs from 20 females (approximately 600 eggs) was homogenized with Freund's complete adjuvant $(1: 1)$ and injected subcutaneously into male New Zealand White rabbits. Each rabbit received five subsequent injections, given with Freund's incomplete adjuvant, at an interval of 7-15 days. A total of about 3600 eggs from 120 mice was used. Serum, obtained 7 days after the last injection, was heated at $56^{\circ} \mathrm{C}$ for $30 \mathrm{~min}$. The antiserum was absorbed with mouse kidney and liver, ovary or spermatozoa; one part of kidney and liver or ovary was homogenized in four parts of PBS. These tissue homogenates and the antiserum, in a ratio of $1: 1$, were allowed to react at $37^{\circ} \mathrm{C}$ for $60 \mathrm{~min}$ and then centrifuged at $10,000 \mathrm{~g}$ for $15 \mathrm{~min}$. Supernatant fluid was again mixed with fresh tissue homogenates and reacted at $4^{\circ} \mathrm{C}$ for $24 \mathrm{~h}$ and then centrifuged at the same speed. For absorption of antiserum with spermatozoa, mouse spermatozoa were recovered from the cauda epididymidis of mature mice and suspended in PBS to a concentration of $19 \times 10^{6}$ spermatozoa $/ \mathrm{ml}$. The suspension was frozen and thawed 10 times and homogenized, the homogenate being used for absorption of antiserum as described above. A crude $\gamma$-globulin fraction was obtained from the antiserum by precipitation with saturated ammonium sulphate and dissolved in PBS. The solution was dialysed against modified Krebs-Ringer bicarbonate buffer, $\mathrm{pH} 7 \cdot 4$ (Toyoda, Yokoyama \& Hosi, 1971) for 6 days and powdered by freeze drying.

The medium for in-vitro fertilization, the preparation of sperm suspensions, and the methods of insemination and examination of eggs for fertilization followed procedures reported elsewhere (Tsunoda \& Chang, 1975a, b). The eggs were treated with medium (without BSA) containing $10 \mathrm{mg}$ antiserum $/ \mathrm{ml}$ or normal serum (non-immunized rabbit serum) $\gamma$-globulin fractions for $30 \mathrm{~min}$ at $37^{\circ} \mathrm{C}$ before insemination. Zona-free eggs were obtained by treating the denuded eggs with $0.2 \%$ pronase for $10 \mathrm{~min}$ and washing several times. Eggs were exposed to medium containing $10 \mathrm{mg}$ antiserum $/ \mathrm{ml}$ for $10 \mathrm{~min}$ at $37^{\circ} \mathrm{C}$ and examined under dark-field illumination for the presence of a zona precipitate. Some intact eggs were exposed to antiserum and to $0.5 \%$ pronase for $60 \mathrm{~min}$ at $20^{\circ} \mathrm{C}$ to determine the time for dissolution of the zona pellucida.

To examine the effect on fertilization of passive immunization with anti-egg serum, $10 \mathrm{mg}$ $\gamma$-globulin in $0.2 \mathrm{ml}$ Ringer solution were injected intraperitoneally to females in which superovulation had been induced at the time of the PMSG injection (Tsunoda \& Chang, 1976d). 
Eggs were considered to be fertilized when an enlarged sperm head(s) or pronuclei with accompanying sperm tail(s) was observed.

When eggs were treated with unabsorbed antiserum or antiserum absorbed with mouse liver and kidney or spermatozoa, the surfaces developed strong light-scattering properties (zona precipitate) under dark-field illumination and became resistant to pronase. The zona precipitate and resistance to pronase were observed whether or not cumulus cells were present. The precipitate was not seen when the eggs were treated with antiserum absorbed with ovary. Zona dissolution of the eggs treated with normal serum and antiserum absorbed with ovary occurred within 10-15 min, but zona dissolution of eggs treated with unabsorbed antiserum or antiserum absorbed with liver and kidney or spermatozoa had not occurred by $1 \mathrm{~h}$.

Table 1. Inhibitory effect of anti-mouse egg serum on fertilization in the mouse

\begin{tabular}{|c|c|c|c|c|c|c|}
\hline \multirow[b]{4}{*}{ Serum } & \multirow{4}{*}{$\begin{array}{l}\text { Conc. in } \\
\text { medium } \\
(\mathrm{mg} / \mathrm{ml})\end{array}$} & \multirow{2}{*}{\multicolumn{3}{|c|}{ In vitro }} & \multicolumn{2}{|c|}{ In vivo } \\
\hline & & & & & \multirow{3}{*}{$\begin{array}{l}\text { No. of females } \\
\text { with fertilized } \\
\text { eggs/no. of } \\
\text { females mated }\end{array}$} & \multirow{3}{*}{$\begin{array}{c}\text { No. of eggs } \\
\text { fertilized } / \text { no. of } \\
\text { eggs examined } \\
(\%)\end{array}$} \\
\hline & & \multicolumn{3}{|c|}{ No. of eggs fertilized/no. of eggs examined $(\%)$} & & \\
\hline & & Intact eggs & Denuded eggs & Zona-free eggs & & \\
\hline Normal & 5 & - & 一 & 一 & $5 / 5$ & $32 / 33(97 \cdot 0)$ \\
\hline immunized) & 10 & $31 / 61(50 \cdot 8)$ & $25 / 51(49 \cdot 0)$ & $25 / 49(51 \cdot 0)$ & $5 / 5$ & $89 / 94(94 \cdot 7)$ \\
\hline \multirow{5}{*}{$\begin{array}{l}\text { Anti-egg } \\
\text { Absorbed } \\
\text { with liver } \\
\text { and kidney }\end{array}$} & & & & & & \\
\hline & 1 & - & - & - & $2 / 3$ & $30 / 36(83 \cdot 3)$ \\
\hline & $2 \cdot 5$ & - & 一 & - & $2 / 4$ & $11 / 48(22 \cdot 9)$ \\
\hline & 5 & - & - & - & $2 / 6$ & $3 / 60(5 \cdot 0)$ \\
\hline & 10 & $0 / 57(0)$ & $0 / 102(0)$ & $20 / 37(54 \cdot 1)$ & $0 / 4$ & $0 / 42(0)$ \\
\hline \multicolumn{7}{|l|}{ Absorbed with } \\
\hline $\begin{array}{l}\text { ovary } \\
\text { Absorbed with }\end{array}$ & 10 & $34 / 65(52 \cdot 3)$ & $29 / 65(44 \cdot 6)$ & $\rightarrow$ & $5 / 5$ & $49 / 50(98 \cdot 0)$ \\
\hline spermatozoa & 10 & - & - & - & $0 / 3$ & $0 / 41(0)$ \\
\hline Unabsorbed & 10 & - & 一 & - & $0 / 3$ & $0 / 64(0)$ \\
\hline
\end{tabular}

The effect of the anti-egg serum fractions on fertilization in mice is shown in Table 1. Fertilization of mouse eggs in vitro was completely inhibited when the eggs, with or without cumulus cells, were treated with antiserum absorbed with liver and kidney, but was not inhibited when the eggs were treated with normal serum or antiserum absorbed with ovary. When zona-free eggs were used, there was no significant difference between the eggs treated with normal serum or anti-egg serum fractions absorbed with liver and kidney. Fertilization in vivo was inhibited by passive immunization with all the antiserum fractions at the highest dose used except that absorbed with ovary. The unfertilized eggs had precipitate on the zona pellucida. Lower doses of the antiserum fraction absorbed with liver and kidney considerably inhibited fertilization, but the lowest dose (1 mg/animal) was ineffective in preventing fertilization.

The levels of fertilization observed in vitro in these experiments are considerably lower than those reported in earlier work (Tsunoda \& Chang, 1975a, b). This could be due to the strain used because Parkening \& Chang (1976) observed high fertilization in vitro for CD-1 mice and lower rates for C57BL/6 mice.

The anti-mouse egg serum used in the present study did not show any precipitin bands against antigens such as ovary, spermatozoa, serum, testis + epididymis, liver, small intestine, lung, uterus, kidney and heart when tested by agar-gel diffusion and immunoelectrophoresis. This result was not in accord with those of Glass \& Hanson (1974) who observed that 1-3 precipitin lines were present when an anti- 
serum to mouse cumulus-oocyte masses was tested against mouse serum by immunoelectrophoresis. The results of the present study also differ from the observation of Ownby \& Shivers (1972) that anti-hamster ovary serum absorbed with small intestine and lung showed one precipitin band against hamster ovary by agar-gel diffusion test.

Because the zona pellucida is one of the most antigenic components in the ovary (Glass \& Hanson, 1974), the inhibition of fertilization caused by anti-ovary serum has been considered to be due to zona-specific antigens. The results of the present study with anti-egg serum, resulting in eggs showing a zona precipitate, zona resistance to pronase and a low fertilization rate, confirm this belief, but there is a lot of work to be done before the isolated zona pellucida can be used as an antigen for developing a specific vaccine for contraceptive purposes.

Thanks are due to Dr T. Sugie and Dr J. Mori for their advice and reading the manuscript, Dr T. Morichi for freeze-drying the $\gamma$-globulin fraction of antiserum, and Dr S. Shibuya for reading the manuscript.

\section{References}

Glass, L.E. \& Hanson, J.A. (1974) An immunologic approach of contraception: localization of antiembryo and antizona pellucida serum during mouse preimplantation development. Fert. Steril. 25, 484 493.

Jilek, F. \& Pavlok, A. (1975) Antibodies against mouse ovaries and their effect on fertilization in vitro and in vivo in the mouse. J. Reprod. Fert. 42, 377380.

OikaWA, T. \& YANAGIMACHI, R. (1975) Block of hamster fertilization by anti-ovary antibody. J. Reprod. Fert. 45, 487-494.

OWNBy, C. L. \& Shrvers, C. A. (1972) Antigens of the hamster ovary and effects of anti-ovary serum on eggs. Biol. Reprod. 6, 310-318.

Parkenino, T.A. \& Chang, M.C. (1976) In-vitro fertilization of ova from senescent mice and hamsters. J. Reprod. Fert. 48, 381-383.

PORTER, C.W. (1965) Ovarian antibodies in female guinea pigs. Int. J. Fert. 10, 257-260.

Shivers, C.A., Dudkiewicz, A.B., Franklin, L.E. \& FUSSELL, E.N. (1972) Inhibition of sperm-egg interaction by specific antibody. Science, N.Y. 178, 12111213.

Toyoda, Y., Yoxoyama, M. \& Hosi, T. (1971) Studies on the fertilization of mouse eggs in vitro. I. In vitro fertilization of eggs by fresh epididymal sperm. Jap. J. Anim. Reprod. 16, 147-151.

Tsunoda, Y. \& Chang, M.C. (1975a) Penetration of mouse eggs in vitro: optimal sperm concentration and minimal number of spermatozoa.J. Reprod. Fert. 44, 139-142.

Tsunoda, Y. \& Chang, M.C. (1975b) In vitro fertilization of rat and mouse eggs by ejaculated sperm and the effect of energy sources on in vitro fertilization of rat eggs. J. exp. Zool. 193, 79-86.

TsunOda, Y. \& ChANG, M.C. (1976a) In vivo and in vitro fertilization of hamster, rat and mouse eggs after treatment with anti-hamster ovary antiserum. J. exp. Zool. 195, 409-416.

Tsunoda, Y. \& Chang, M.C. (1976b) Effect of anti-rat ovary antiserum on the fertilization of rat, mouse and hamster eggs in vivo and in vitro. Biol. Reprod. 14, 354-361.

Tsunoda, Y. \& Chang, M.C. (1976c) Reproduction in rats and mice isoimmunized with homogenates of ovary or testis with epididymis, or sperm suspensions. J. Reprod. Fert. 46, 379-382.

Tsunoda, Y. \& Chang, M.C. (1976d) Effect of passive immunization with hetero and isoimmune anti-ovary antiserum on the fertilization of mouse, rat and hamster eggs. Biol. Reprod. 15, 361-365.

Received 7 Decenber 1976 